\title{
Evaluation of amylase activity in patients with type 2 daibetes mellitus
}

\author{
Mufeed Jalil Ewadh*, Thana Mohammed Juda, Zinah Abbas Ali, Muna Mufeed Ewadh \\ Babylon University, College of Medicine, Biochemistry Dept. Hilla, Iraq
}

Email address:

mewadh@yahoo.com (M. J. Ewadh)

To cite this article:

Mufeed Jalil Ewadh, Thana Mohammed Juda, Zinah Abbas Ali, Muna Mufeed Ewadh. Evaluation of Amylase Activity in Patients with

Type 2 Daibetes Mellitus. American Journal of BioScience. Vol. 2, No. 5, 2014, pp. 171-174. doi: 10.11648/j.ajbio.20140205.11

\begin{abstract}
Diabetes mellitus is a chronic metabolic disorder which is associated with hyperglycemia. It is caused by a derangement in the secretion or function of the endocrinal portion of the pancreas. There is a close anatomical and functional relationship between its exocrine and endocrine portions. The current study was designed to evaluate the changes in amylase levels in diabetic patients and study the correlation of amylase activity with chronic hyperglycemia and duration of diabetes mellitus. The results of study were revealed that amylase activity was low in diabetic patients compared with control and there was negative correlation between amylase activity and hyperglycemia and duration .
\end{abstract}

Keywords: Amylase Activity, Diabetes Mellitus, Endocrine

\section{Introduction}

Diabetes mellitus is a metabolic disorder characterized by the presence of abnormally high blood glucose levels (hyperglycemia). It is caused by defective in insulin secretion, defective action or both [1]. Individuals with uncontrolled diabetes mellitus are unable to transport glucose into fat and muscle cells and are thus said to demonstrate glucose intolerance [2]. The classic symptoms of diabetes are excessive urination (polyuria), thirst (polydipsia) and (polyphagia), and weight loss [3]. Diabetes is now ranked among one of the most common non-communicable diseases in the world. It falls within 4th-5th leading cause of death in most developed countries [4].

The pancreas is a mixed exocrine-endocrine gland, with the exocrine portion of the gland making up the greatest volume (84\%). Ductal cells and blood vessels make up around $4 \%$ of the volume, while the endocrine part makes up $2 \%$ of the volume. The other part $(10 \%)$ is occupied by an extracellular matrix. The acinar tissue in the pancreas is in the close vicinity of the islets. Because of this close morphological relationship, functional interactions are likely to occur between the exocrine and endocrine pancreas in any disease, which affect this organ [5].

Anatomically, the blood from the islets bathes the acinar cells by way of an islet-exocrine portal system [6]. There is also morphological evidence that indicates that the pancreatic exocrine function may be influenced by the pancreatic endocrine hormones. Insulin has a trophic effect on the exocrine pancreas, especially on the peri-insular acini. A progressive damage to the pancreatic acinar cells is seen in insulin deficiency. The pancreatic exocrine tissue in a diabetic patient becomes fibrosed and it shows a reduced response to the hormonal stimulation $[7,8]$.

Clinical investigation observations indicate close relation between pancreatic exo- and endocrine parts. Insulin dysfunction and glucagon activation is due to pancreatic impairment The decreased production of exocrine secretion also influence on insulin deficiency (Interestingly, the relation between insulin and glucagon concentrations in extracellular fluid and their antagonistic actions also seem to play a key role in pancreatic exocrine function disorders. Insulin secretion is enhancing the exocrine activity like alpha amylase functions but glucagon inhibits it [9]. Diabetes mellitus and exocrine pancreatic dysfunction in perk-/- mice reveals a role for translational control in secretary cell survival [10].

In type 2 Diabetes mellitus, the continuous interstitial matrix connection between the endocrine and the exocrine pancreas is lost in animal models and humans, which results in a dysfunctional insulino-acinar-ductal-incretin gut 
hormonal axis [11]. Besides these putative mechanisms, there are multiple defects in the insulin secretion and the signaling in type 2 diabetes, which may affect the enzyme synthesis and release in the exocrine pancreas [12]. Not only this, also, the secretion of the pancreatic juice is controlled by the autonomic nervous system and by the naturally occurring gut hormones, cholecystokinin and secretin. This complex interplay is often found to be disturbed in diabetes due to the well-known complications of autonomic neuropathy and the micro vascular complications, which are so common in Diabetes mellitus [13].

Amylase is derived from the Greek word "amylone," which means starch. The main sources of amylase in humans are the pancreas and salivary glands, but it can be found in other tissues in small quantities. The main function of amylase is to cleave starch into smaller polysaccharides at the internal 1 to 4 alpha linkage in the process of digestion $[14,15]$.

For many years, low serum amylase was thought to reflect diffuse pancreatic destruction secondary to advanced pancreatic diseases, such as chronic pancreatitis [16]. Recently, several large clinical studies have shown that low serum amylase is also associated with metabolic syndrome and diabetes[17-19]. Disturbance of serum amylase is associated with insulin deficiency in patients with type 1diabetes and, less commonly, with type 2 diabetes[20-22], as well as the pathogenesis of insulin resistance in obese animal models [23,24]. Because serum amylase can be classified as pancreatic-type and salivary-type amylase, it is often necessary to distinguish between the two types for precise clinical diagnosis .Nevertheless, the measurement of serum amylase is useful to determine the pathogenesis of many diseases [25-27].

\section{Material and Methods}

The study was conducted on normal healthy volunteers and diabetic patients referred to Consultation Medical Laboratory at Al-Hilla Teaching Hospital after recording their age and gender patients group were type 2 Diabetes mellitus, who were already diagnosed and were taking treatment, were included in this study and compared with age and sex matched healthy individuals group in our study. Fasting venous blood samples were collected from the patients as well as the controls and they were analyzed for blood glucose and serum amylase was measured according to the method of Ethylidine-paranitrophenol glucose EPNPG7 .This technique is based on the hydrolysis of pnitrophenylmaltoheptose to produce glucose and $\mathrm{p}$ nitrophenylate, the concentration of the latter is measured at $405 \mathrm{~nm}$. The concentration of p-nitrophenylate is proportional to the activity of the enzyme. One International Unit (IU) was considered as the amount of enzyme that hydrolyzes $1 \mathrm{mmol}$ of substrate. The results were analyzed statistically by using the Student's " $t$ " test and correlation coefficients.

\section{Results}

This study was considered to assess the possible exocrine-endocrine relationship of the pancreas, by evaluating the serum amylase levels and the blood glucose in the two groups diabetic patients and healthy control serum amylase activity estimated and the result representing in table no. 1

Table (1). Serum Amylase activity in diabetic patients and control.

\begin{tabular}{lllll}
\hline \multirow{2}{*}{\begin{tabular}{l} 
IUd $/ \mathbf{L}$ \\
\cline { 2 - 5 }
\end{tabular}} & Groups & Mean \pm SD & Range & P Value \\
\cline { 2 - 5 } & Control & $9.2 \pm 5.3$ & $5-13$ & \multirow{2}{*}{0.003} \\
\hline
\end{tabular}

Correlation of serum amylase with fasting blood glucose in diabetic patients are representing in figure no. 1

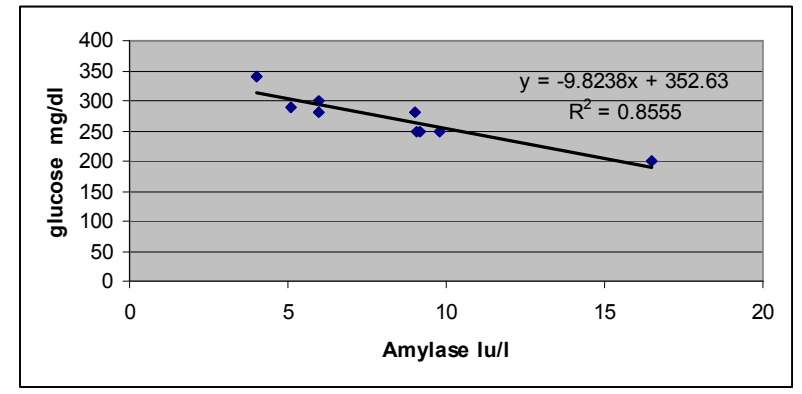

Figure (1). correlation of serum amylase activity with blood glucose.

Study was revealed negative significant correlation of activity of amylase with duration of diabetes mellitus and the correlation coefficient was $(-0,8)$ and this result are representing in figure no. 2

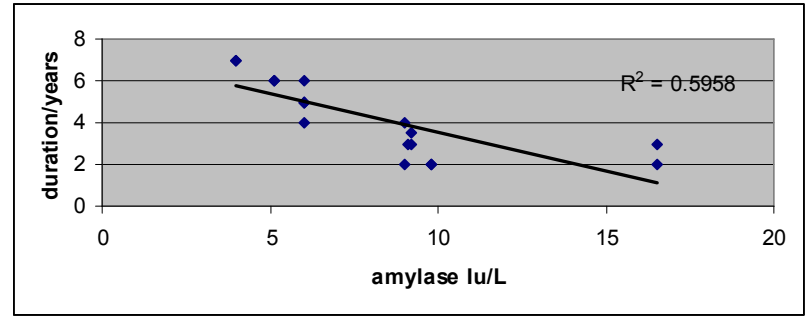

Figure 2. Correlation of amylase activity with duration of diabetes mellitus

\section{Discussion}

Diabetes mellitus is one of the most common chronic diseases, which endangers the life of millions of population all over the world .It is manifested by hyperglycemia and lowered serum insulin value, and has been classified into type 1 (IDDM) and type 2 (NIDDM) according to the age onset of the disease and the need for insulin therapy.

Complications of diabetes are due to pathologic changes that involve large blood vessels, cranial and peripheral nerves, the skin, and the lens of the eye. Macrovascular complications involve damage to the large blood vessels of the brain, heart, and extremities [28]. Microvascular 
complications of diabetes include retinopathy, nephropathy and neuropathy [29].

The majority of diabetic research has been focused on normalization of hyperglycemia and abnormal lipid profile to the other hand, very little concern on pancreatic exocrine function in diabetes has been paid. The present study, investigated the changes in serum pancreatic amylase in type 2 diabetic patients compared with normal healthy individuals.

By study the amylase activity in this work revealed that decrease in activity of amylase in diabetic patients in comparism with control and there is significant difference at $\mathrm{p}$ value $<0.05$.

Low level of amylase in the body is mostly resulted due to consumption of high amounts of carbohydrates. This is the case with amylase deficiency in people with fat intolerance. Amylase catalyzes starch and complex carbohydrates. So, the higher the amount of these nutrients in the body, the more is the requirement of amylase. Eventually, the level of amylase falls down from the normal recommended level, thus manifesting amylase deficiency symptoms[30,31].

Diabetes does not only cause impairment in the metabolism of sugars but is also associated with abnormal metabolism of fats and proteins. Therefore all three key enzymes - lipase, protease and amylase - are important in managing diabetes because they will help digest all three groups of nutrients: proteins, fats and sugars[16].

\section{Conclusions}

Although most of diabetic research has been focused on dyslipidemia as a major risk factor for cardiac, cerebral and renal complications, the present study clearly illustrates an impairment of pancreatic exocrine function in type 2 diabetes mellitus. The suggestion that an analysis of serum pancreatic enzymes could be an additional informative parameter for the assessment of chronic and progress of the illness as well as the response to therapy.

\section{References}

[1] American Diabetic Association. (2010) Standards of medical care in diabetes-. Diabetes Care,; 33 (Suppl. 1), S11-S61.

[2] Bechmann L. P,. Hannivoort R. A,. Gerken G,., and. Canbay A . (2012) The interaction of hepatic lipid and glucose metabolism in liver diseases. Journal of Hepatology, ; 56: 4: pp. 952-964

[3] Report of the Expert Committee on the Diagnosis and Classification of Diabetes Mellitus .(2003) Diabetes Care .,; 26(Supplement 1), S5-16.

[4] Helaine E., Resnick M . (June 2013) Diabetes Care;36 (6): 1431-1432.

[5] Singh J, Yago MD, Adeghate E.( 1999) The role of insulin, glucagon, somatostatin, cholecystokinin, acetylcholine and nerve stimulation in the interactions between the endocrine and exocrine pancreas in normal and diabetic conditions in rats. Int J Diabetes;7(1):114-19.

[6] Bertelli E, Bendayan M.( 2005) Association between endocrine pancreas and ductal system. More than an epiphenomenon of endocrine differentiation and development. J Histochem Cytochem.;53(9):1071-86.

[7] Drucker DJ.(2007) The role of gut hormones in glucose homeostasis. J Clin Invest.;117:24-32.

[8] Barreto SG, Carati CJ, Toouli J, Saccone GT.( 2010)The Islet-acinar Axis of Pancreas: More than Just Insulin. Am J Physiol Gastrointest Liver Physiol.;299:G10-22.

[9] H.P., H. Zeng, Y. Zhang, R. Jungries and P. Chung et al., (2001) Mol Cell 7(6):1153-63.

[10] Lernmark, A., (2000). Rapid-onset type 1 diabetes with pancreatic exocrine dysfunction. N. Engl. J. Med., 342: 344345

[11] Hayden MR, et al.( 2008):Attenuation of endocrine-exocrine pancreatic communication in type 2 diabetes: pancreatic extracellular matrix ultra structural abnormalities. J Cardio metab. Syndr.;3:234-43.

[12] American Diabetes Association. Diagnosis and classification of diabetes mellitus. (2010)Diabetes Care. 33(Suppl 1):S6269.

[13] Swislocki A, Noth R, Hallstone A, Kyger E, Triadafilopoulos G: (2005)Secretin stimulated amylase release into blood is impaired in type 1 diabetes mellitus. Horm Metab Res, 37:326-330.

[14] Yegneswaran B, Pitchumoni CS (2010)When should serum amylase and lipase levels be repeated in a patient with acute pancreatitis? Cleve Clin J Med, 77:230-231.

[15] Skrha J, Stěpán J: (1987)Clinical significance of amylase isoenzyme determination. Acta Univ Carol Med Monogr, 120:1-81.

[16] Aughsteen AA, Abu-Umair MS, Mahmoud SA.( 2005) Biochemical analysis of serum pancreatic amylase and lipase enzymes in patients with type 1 and type 2 diabetes mellitus. Saudi Med J, 26:73-77.

[17] Jeong Gyu Leea.( 2011) Sang Wook ParkByung Mann Cho Serum amylase and risk of the metabolic syndrome in Korean adultsClinica Chimica ActaVolume 412, Issues 1920, 18 September, Pages 1848-1853 .

[18] American Diabetes Association. (2010) Diagnosis and classification of diabetes mellitus. Diabetes Care,33(Suppl 1):S62-S69.

[19] Chiolero A, Faeh D, Paccaud F, Cornuz J. (2008) Consequences of smoking for body weight, body fat distribution, and insulin resistance. Am J Clin Nutr, 87:801809 .

[20] Lee JG, Park SW, Cho BM, Lee S, Kim YJ, Jeong DW, Yi YH, Cho YH: (2011) Serum amylase and risk of the metabolic syndrome in Korean adults. Clin Chim Acta., 412:1848-1853.

[21] Nakajima K, Muneyuki T, Munakata H, Kakei M: (2011) Revisiting the cardiometabolic relevance of serum amylase. BMC Res Notes., 4:419. 
[22] Martin SS, Qasim A, Reilly MP: (2008) Leptin resistance: a possible interface of inflammation and metabolism in obesity-related cardiovascular disease. J Am Coll Cardiol, 52:1201-1210.

[23] Gautron L, Elmquist JK.( 2011)Sixteen years and counting: an update on leptin in energy balance. J Clin Invest, 121(6):2087-2093. doi:10.1172/JCI45888.

[24] Rundy SM, Cleeman JI, Daniels SR, Donato KA, Eckel RH, Franklin BA, Gordon DJ, Krauss RM, Savage PJ, Smith SC Jr, Spertus JA, Costa F. (2005) American Heart Association; National Heart, Lung, and Blood Institute: Diagnosis and management of the metabolic syndrome: an American Heart Association/National Heart, Lung, and Blood Institute Scientific Statement.Circulation,112:2735-275

[25] Skrha J, Stěpán J. (1987) Clinical significance of amylase isoenzyme determination. Acta Univ Carol Med Monogr, 120:1-81.

[26] Pieper-Bigelow C, Strocchi A, Levitt MD. (1990) Where does serum amylase come from and where does it go? Gastroenterol Clin North Am, 19:793-810.

[27] Nakajima K, Muneyuki T, Munakata H, Kakei M. (2011) Revisiting the cardiometabolic relevance of serum amylase. BMC Res Notes., 4:419.

[28] Kahn S., Andrikopoulos S., Verchere C. (1999). Islet amyloid: a long-recognized but underappreciated pathological feature of type 2 diabetes. Diabetes.;48:241-25

[29] SachdevoY. "Clinical Endocrinology and diabetes mellitus(A comprehensive text)., 2008; Vol 2,first ed :908909.

[30] Martin SS, Qasim A, Reilly MP. (2008) Leptin resistance: a possible interface of inflammation and metabolism in obesity-related cardiovascular disease. J Am Coll Cardiol, 52:1201-1210.

[31] Toshitaka .,Aksushi A. (2012) latent association of low amylase activity with decrease plasma insulin level .cardiovascdaibetes j .;11:(80) 